Chirurgia (2018) 113: 344-352

No. 3, May - June

Copyright@ Celsius

http://dx.doi.org/10.21614/chirurgia.113.3.344

\title{
Is Hepatitis B Virus a Player in Pancreatic Cancer?
}

\author{
Traian Dumitrascu ${ }^{1,2}$, Pascal Pineau ${ }^{3}$ \\ ${ }^{1}$ Fundeni Clinical Institute, "Dan Setlacec" Center of General Surgery and Liver Transplant, Bucharest \\ 2"Carol Davila" University of Medicine and Pharmacy, Bucharest, Romania \\ 3Unité "Organisation nucléaire et oncogenèse", INSERM U993, Institut Pasteur, Paris, France
}

Corresponding author:

Traian Dumitrascu, MD

"Dan Setlacec" Center of General

Surgery and Liver Transplant

Fundeni Clinical Institute

Fundeni Street no 258, 022328

Bucharest, Romania

E-mail: traian.dumitrascu@umfcd.ro
Received: 14.04 .2018

Accepted: 20.05 .2018

\section{Rezumat}

Este virusul hepatitic B un jucător în cancerul de pancreas?

Cancerul de pancreas (carcinomul ductal, PDAC) reprezintă o problemă importantă de sănătate publică având letalitate ridicată. Astfel, aproximativ 80\% dintre pacienții cu PDAC decedează în primul an de la momentul stabilirii diagnosticului. Factori de risc precum fumatul, obezitatea, vârsta înaintată, diabetul zaharat şi pancreatita cronică au fost asociați cu apariția PDAC. Virusul hepatitic B (HBV) este deasemenea considerat un factor de risc pentru aparitia PDAC în unele studi. Totuşi, rolul HBV în PDAC este insuficient documentat. Lucrarea de față trece în revistă cercetările existente ce explorează impactul HBV în PDAC. Evaluarea impactului HBV în PDAC este dificilă deoarece efectele infecției virale pot fi uşor subestimate. Intr-adevăr, rolul jucat de infecția ocultă HBV şi dificultățile întâmpinate în detecția antigenului HBV sau a ADN-ului HBV în țesutul pancreatic reprezintă limitări importante în cercetarea acestor aspecte. La momentul actual, există suficiente date în literatură care să sugereze potențialul rol oncogenic al HBV în PDAC, dar datele din studiile experimentale sunt puține. In plus, se pare că HBV ar avea influență asupra unor factori clinici şi patologici ai pacienților cu PDAC. Studii viitoare care să definească mai bine rolul HBV în apariția PDAC sunt imperios necesare.

Cuvinte cheie: virusul hepatitic B, infecție ocultă, cancer pancreatic, epidemiologie, factor de risc, rezultate 


\begin{abstract}
Pancreatic cancer (i.e., pancreatic ductal adenocarcinoma, PDAC) is an important healthcare issue and a highly lethal disease. Thus, almost $80 \%$ of patients with PDAC will die within one year after diagnosis. Several factors including smoking, obesity, advanced age, diabetes mellitus and chronic pancreatitis have been associated with increased risk of PDAC. Hepatitis B virus (HBV) infection is also considered as a risk factor for PDAC development in some studies. However, the role of HBV infection in PDAC is poorly explored. The present paper reviews the current relevant literature exploring the impact of HBV infection in PDAC. Assessment of HBV infection impact in PDAC is challenging because its effects could be easily underestimated. Indeed, the role played by occult B infection (OBI) and intrinsic difficulties to detect HBV antigens or DNA in pancreatic tissue remains major limitations to further progress. To date a significant proportion of available literature suggests the potential oncogenic role of HBV in PDAC but experimental evidences remain scarce. Remarkably, it appears that HBV infection might influence some clinical and pathological features of patients with PDAC. Future researches to better define the role of HBV infection in developing PDAC are urgently needed.
\end{abstract}

Key words: hepatitis B virus, occult B infection, pancreatic cancer, epidemiology, risk factor, outcomes

\section{Introduction}

Pancreatic cancer (i.e., pancreatic ductal adenocarcinoma, PDAC) is an important healthcare issue and a highly lethal disease (1-3). Thus, more than $50 \%$ of patients present distant metastases at diagnosis and the estimated 5-year survival rate for all stages is around 8\% (4).

Overall, it appears that extremely modest improvements of survivals were observed for PDAC over the years $(3,4)$, despite substantial treatment evolutions in the last 20 years $\left(1,5^{-}\right.$ 10). As a consequence, the short-term survival rate remains dismal with almost $80 \%$ of patients with PDAC who die within one year after diagnosis (2).

Pancreatic resection represents the single hope for long-term survival in PDAC but few patients are suitable for such intervention at the time of diagnosis $(1,3,11)$. Interestingly, although more patients with PDAC undergo pancreatectomies $(2,8)$, with improved median survivals (8), it appears that the 5-year survival rates after resection for PDAC did not improved significantly in the last period (8). Nevertheless, although long-term survival in patients with PDAC is widely considered as extremely rare, the 5-year survival rate in resected patients is by far much better (i.e., $10.1 \%$ ), compared with the 5-year survival rates of localized unresected or metastatic PDAC (i.e., $0.5 \%$ and $0.1 \%$, respectively)(12).

PDAC is subjected to geographical disparities regarding both its incidence and its mortality (13). Thus, the largest part of patients with PDAC is coming from Western Pacific, Europe and Americas (13). Unfortunately, the worldwide incidence rate of PDAC almost equals its mortality rate betraying its universal high lethality (13).

The predicted number of deaths from PDAC for 2018 is 44500 in men and 44400 in women in Europe (14) and 23020 in men and 21310 in women in the United States (4). Although PDAC is not in top 5 of the most frequent forms of cancers in both sexes (it ranks in $15^{\text {th }}$ position), it represents, however, the $4^{\text {th }}$ cause of deaths by cancer both in men and women (4). Furthermore, although PDAC shows stable rates in men, in women a steady rise is observed in Europe (14). Conversely, in the United States, PDAC shows stable rates in women and a rise in men (4). Moreover, the global burden of PDAC (incidence and mortality rates) is expected to rise significantly over the next few decades regardless 
of age, gender or geographic location (13).

Hepatitis B virus (HBV) remains a topic of constant worries today although tremendous progresses have been made to overcome the burden of HBV infection(15).

A recent study has shown a mean global prevalence of hepatitis B surface antigen ( $\mathrm{HBsAg}$ ) carriage, that betrays persistent infection, of $4.9 \%$, with considerable geographical disparities (16). Thus, the highest prevalence was observed in Africa and Western Pacific $(7.1 \%$ - 9.5\%)(16). Conversely, the lowest prevalence was observed in Americas and Europe $(0.6 \%-2 \%)(16)$.

Immunization dramatically reduced the burden of HBV infection in many countries and the role of the virus in hepatocellular carcinoma (HCC) epidemiology is predicted to decrease (17). Noticeably, the World Health Organization aims to eliminate HBV by 2030 (16).

It is worth to highlight the outstanding research on HBV of Pierre Tiollais and $\mathrm{co}^{-}$ workers at Institut Pasteur in Paris(18-20), a place where the first cloning and sequencing of HBV genome was performed (21). The work of Pierre Tiollais and co-workers was a significant contribution to better understanding of $\mathrm{HBV}$ biology, its role in carcinogenesis and obtaining effective therapies, including vaccination. Thus, as an outcome of his research and that of others, millions of lives have been saved all over the world.

The role of HBV in pathogenesis of $\mathrm{HCC}$ has been highlighted for a long time $(18 ; 22 ; 23)$. Moreover, not only patients with HBV are at high risk for developing HCC (24-26) but it appears that HBV infection modulates clinicopathological features and long-term outcomes in HCC-treated patients (27,28).

$\mathrm{HBV}$ is a hepatotropic virus that is detected in several types of extra-hepatic tissues, including the pancreas (29-35). It is, therefore, considered to play a role in the development of extra-hepatic malignancies $(25,26,36,37)$, including PDAC $(25,29,33,37,38)$. However, detection of $\mathrm{HBV}$ in extra-hepatic tissues is challenging $(29,31)$ and might explain the paucity of studies addressing this issue (38). It appears that detection of HBV DNA represents the most accurate method to demonstrate the presence of HBV in extra-hepatic organs (29), and it is worth to mention the merit of Dejean and co-workers in Institut Pasteur to first extract HBV DNA from pancreas (30). Remarkably, HBV was shown to not only infect but also to replicate in the tumor and nontumorous pancreatic tissue of patients with PDAC (33). As low levels of HBV replication are usually observed in pancreatic cancer cells, it is not surprising that molecular data about the potential role of $\mathrm{HBV}$ in PDAC remain scarce (31,33).

The present paper reviews the current relevant literature exploring the impact of HBV in PDAC

\section{Is HBV infection a risk factor for PDAC? - Current evidence from epidemiological studies}

Nowadays several factors have been associated with an increased risk of PDAC. Thus, smoking, obesity, alcohol abuse, male gender, advanced age, diabetes mellitus and chronic pancreatitis are widely considered the main risk factors for developing PDAC (3,39-43). In addition, infectious factors such as Helicobacter pylori have been associated with an increased risk of developing PDAC $(39,43)$.

Several epidemiological studies, reaching conflicting conclusions, have explored the potential role of HBV as risk factor for PDAC (Table 1).

Hassan and co-workers in a study at M.D. Anderson Cancer Center have found that patients without HBsAg itself but positive for antibodies directed towards hepatitis B core protein (anti-HBc) with $(\mathrm{OR}=2.3)$ or without $(\mathrm{OR}=4.0)$ antibodies directed against hepatitis $\mathrm{B}$ surface antigen (anti-HBs) have an increased risk of developing PDAC(40). This observation suggests that past exposure to HBV or possible occult B infection (OBI) might represent risk factors for PDAC. In addition, in this series exposure to HBV was greatly increasing PDAC risk $(\mathrm{OR}=7.1)$ in diabetics.

The REVEAL-HBV study, in Taiwan, has shown that $\mathrm{HBsAg}(+)$ patients, in the settings either of a chronic active infection or inactive 
Table 1. Epidemiological studies exploring in multivariate analyses the association of HBV infection biomarkers with the risk of pancreatic cancer development.

\begin{tabular}{|c|c|c|c|c|c|c|c|c|c|}
\hline Author, year & $\mathrm{HBsAg}(+)$ & $\begin{array}{c}\operatorname{HBsAg}(+) / \\
\text { anti-HBc(+) }\end{array}$ & $\begin{array}{c}\text { HBsAg(-)/ } \\
\text { anti-HBc(+) }\end{array}$ & $\begin{array}{l}\text { Anti-HBC(+) } \\
\text { /anti-HBs(+) }\end{array}$ & $\begin{array}{l}\text { Anti-HBc(+)/ } \\
\text { anti-HBs(-) }\end{array}$ & $\begin{array}{c}\operatorname{HBsAg}(+) / \\
\text { HBeAg(-) }\end{array}$ & $\begin{array}{l}\operatorname{HBsAg}(+) / \\
\operatorname{HBeAg}(+)\end{array}$ & $\begin{array}{l}\text { HBsAg(+)/ } \\
\text { HBV viral load } \\
\text { undetectable }\end{array}$ & $\begin{array}{c}\text { HBsAg(+)/ } \\
\text { HBV viral } \\
\text { load detectable }\end{array}$ \\
\hline Hassan, 2008 (40) & - & - & $\begin{array}{c}2.5 \\
(1.5-4.2)\end{array}$ & $\begin{array}{c}2.3 \\
(1.2-4.3)\end{array}$ & $\begin{array}{c}4 \\
(1.4-11.1)\end{array}$ & - & - & - & - \\
\hline $\begin{array}{l}\text { Berrington de } \\
\text { Gonzalez, } 2008 \text { (50) }\end{array}$ & $\begin{array}{c}1.1^{*} \\
(0.8-1.5)\end{array}$ & - & - & - & - & - & - & - & - \\
\hline Iloeje, 2009 (44) & $\begin{array}{c}1.9 \\
(1.1-3.7)\end{array}$ & - & - & - & - & $\begin{array}{c}1.6 \\
(0.7-3.4)\end{array}$ & $\begin{array}{c}5.7 \\
(1.7-19)\end{array}$ & $\begin{array}{c}0.6^{*} \\
(0.1-4.6)\end{array}$ & $\begin{array}{c}2.4 \\
(1.2-4.9)\end{array}$ \\
\hline Hong, 2010 (41) & $\begin{array}{c}0.9^{*} \\
(0.5-1.5)\end{array}$ & - & - & - & - & - & - & - & - \\
\hline Zhu, 2011 (47) & - & - & - & - & - & - & $\begin{array}{c}2.9 \\
(1.1-7.9)\end{array}$ & - & - \\
\hline Ben, 2012 (45) & $\begin{array}{c}1.6 \\
(1.1-2.2)\end{array}$ & - & $\begin{array}{c}1.1^{*} \\
(0.8-1.3)\end{array}$ & $\begin{array}{c}0.8^{*} \\
(0.6-1.1)\end{array}$ & $\begin{array}{c}1.7 \\
(1.2-2.4)\end{array}$ & - & - & - & - \\
\hline Wang, 2012 (46) & - & $\begin{array}{c}1.6 \\
(1.1-2.3)\end{array}$ & - & $\begin{array}{c}1.5 \\
(1.1-2)\end{array}$ & - & - & - & - & - \\
\hline Liao, 2012 (42) & $\begin{array}{c}0.9^{*} \\
(0.3-2.4)\end{array}$ & - & - & - & - & - & - & - & - \\
\hline Huang, 2013 (49) & $\begin{array}{c}2^{*} \\
(0.7-5.3)\end{array}$ & - & - & - & - & & & & \\
\hline Woo, 2013 (53) & $\begin{array}{c}1.1^{*} \\
(0.6-1.5)\end{array}$ & - & - & - & - & - & - & - & - \\
\hline $\begin{array}{l}\text { Sundquist }{ }^{1} \text {, } \\
2014(26)\end{array}$ & $\begin{array}{c}11.3 \\
(2.1-33.4)\end{array}$ & - & - & - & - & - & - & - & - \\
\hline Chang, 2014 (48) & - & $\begin{array}{c}1.2^{\star} \\
(0.8-1.6)\end{array}$ & - & $\begin{array}{c}1.1^{\star} \\
(0.8-1.2)\end{array}$ & - & - & - & - & - \\
\hline Tang, 2014 (51) & - & $\begin{array}{c}1.1^{*} \\
(0.1-7.7)\end{array}$ & - & $\begin{array}{c}1.4^{*} \\
(0.8-2.2)\end{array}$ & - & - & - & - & - \\
\hline Andresen, 2015 (24) & $\begin{array}{c}0.8 \\
(0.3-2.5)\end{array}$ & - & - & - & - & - & - & - & - \\
\hline Kamiza, 2016 (25) & $\begin{array}{c}2.7 \\
(1.7-4.3)\end{array}$ & - & - & - & - & - & - & - & - \\
\hline
\end{tabular}

Data are expressed as odd ratio (95\% confidence intervals); 1only for patients < 30 years; ${ }^{*} P$ values $\geq 0.05, \mathrm{~ns} ; \mathrm{HBsAg}(+) /$ anti- $\mathrm{HBc}(+)$ : chronic carrier; $\mathrm{HBSAg}(-) / \operatorname{anti-} \mathrm{HBC}(+)$ : past exposure; anti-HBc(+)/anti-HBs(+): past exposure with natural immunity; $\mathrm{HBsAg}(+)$ : chronic or inactive carrier;

anti-HBc(+)/anti-HBs(-): possibly chronically infected and have undetectable levels of HBSAg present in the serum (OBI)

carriage, are at increased risk $(\mathrm{OR}=1.95)$ of developing PDAC(44). A higher viral DNA load was also correlated with a high risk of developing PDAC(44).

Ben and co-workers, in a Chinese study from Shanghai, have shown that $\mathrm{HBsAg}(+)$ patients (i.e., active infection or inactive carriers) have an increased risk $(\mathrm{OR}=1.6)$ of developing PDAC (45). By contrast, patients with isolated anti$\mathrm{HBc}$ (i.e., potential OBI) and anti-HBs(+)/anti$\mathrm{HBc}(+)$ patients (i.e. past exposure with natural immunity) were not found to be at risk of PDAC(45). In addition, in this survey, concomitant diabetes mellitus was further increasing the risk of PDAC.
Wang and co-workers, in another Chinese study from Guangzhou (South China), have shown that $\mathrm{HBsAg}(+) / \operatorname{anti}-\mathrm{HBc}(+)$ patients (i.e., chronic carriers) and anti-HBs $(+) /$ anti- $^{-}$ $\mathrm{HBc}(+)$ patients (i.e., previously exposed with natural immunity) are at significant risk $(\mathrm{OR}=1.6$ and 1.5) to develop PDAC (46).

Jin and co-workers in a third Chinese study have shown that patients with isolated anti-HBc (i.e., past exposure and possible OBI) have increased risk of developing PDAC, while HBsAg(+) patients (i.e., chronic active infection or inactive carriers) were not at risk (33). Although a significantly higher proportion of HBV DNA(+) patients was observed in the 
PDAC patients compared with "healthy" controls, however, no differences of viral load levels were observed (33). Interestingly, in more than $70 \%$ of patients with PDAC and positive for HBV DNA, the HBsAg in the serum was not detected suggesting the high prevalence of OBI (33).

Other studies with less convincing outcomes have been published. Kamiza and co-workers in a Taiwanese study have associated HBV infection to PDAC (25). However, the association did not reach statistical significance when patients with $\mathrm{HBV}$ and hepatitis $\mathrm{C}$ virus co-infection were excluded (25). An increased risk of PDAC among HBV patients who were infected at a younger age (i.e., < 30 years at diagnosis of HBV) was suggested in a study performed in Sweden (26). Positivity for HBeAg, a marker of HBV replication, was found to be a risk factor of developing PDAC in a Chinese study (47).

Finally, it is worth to mention that there are also studies such as two Taiwanese studies $(42,48)$, a Swedish study (49), a Chinese study (47), the Japan Public Health Cancer study (50), the Danish Cancer Registry study (24), a US study (51) and three Korean studies
$(41,52,53)$ that did not associate HBV with an increased risk of developing PDAC.

Nevertheless, several meta-analyses have shown that the PDAC risk positively correlates with $\mathrm{HBV}$ infection, particularly for chronic carriers and occult infection (54-61). However, it is worth to mention that most analyzed studies are coming from Asia and were case-control studies with a heterogeneous design of control group (Table 2). Anyhow, some researchers still question the association of $\mathrm{HBV}$ infection with PDAC considering it as a likely coincidence. In any case, the conclusions of meta-analyses and other studies as well should not be generalized and should be interpreted with caution.

\section{What is known about the potential oncogenic mechanisms of HBV infection in PDAC?}

The oncogenic potential of $\mathrm{HBV}$ in PDAC was presumed for a long time(62) but the mechanisms triggered by $\mathrm{HBV}$ in PDAC remain largely unknown. Several hypotheses have been proposed taking into consideration the fact that pancreas and liver share many features in their early embryological growth

Table 2. Meta-analyses exploring the association of HBV infection biomarkers with the risk of pancreatic cancer development

\begin{tabular}{|c|c|c|c|c|c|c|c|c|}
\hline Author, year & $\operatorname{HBsAg}(+)$ & $\begin{array}{c}\operatorname{HBsAg}(+) / \\
\text { anti-HBc(+) }\end{array}$ & $\begin{array}{c}\mathrm{HBsAg}(-) / \\
\text { anti-HBc(+) }\end{array}$ & $\begin{array}{c}\text { Anti-HBc(+)/ } \\
\text { anti-HBs }(+)\end{array}$ & $\begin{array}{c}\text { Anti-HBc(+)/ } \\
\text { anti-HBs(-) }\end{array}$ & $\begin{array}{r}\operatorname{HBsAg}(+) / \\
\operatorname{HBeAg}(+)\end{array}$ & Anti-HBs(+) & Anti-HBe(+) \\
\hline Fiorino, 2013(54) & $\begin{array}{c}1.18 \\
(1.04-1.33)\end{array}$ & - & $\begin{array}{c}1.31 * \\
(0.93-1.84)\end{array}$ & $\begin{array}{c}1.12^{\star} \\
(0.78-1.59)\end{array}$ & - & $\begin{array}{c}1.31^{\star} \\
(0.85-2.02)\end{array}$ & - & - \\
\hline $\mathrm{Li}, 2013(55)$ & $\left(1.13^{1.4}-1.72\right)$ & - & - & - & - & - & - & - \\
\hline Luo, 2013(56) & - & $\begin{array}{c}1.36 \\
(1.16-1.62)\end{array}$ & - & $\begin{array}{c}1.41 \\
(1.06-1.87)\end{array}$ & - & $\begin{array}{c}3.83 \\
(1.76-8.36)\end{array}$ & - & - \\
\hline Wang, 2013(58) & $\begin{array}{c}1.6 \\
(1.26-2.05)\end{array}$ & - & $\begin{array}{c}1.50^{*} \\
(0.92-2.43)\end{array}$ & $\begin{array}{c}1.36^{\star} \\
(0.79-2.32)\end{array}$ & $\begin{array}{c}1.76 \\
(1.05-2.93)\end{array}$ & $\begin{array}{c}1.71 * \\
(0.76-3.82)\end{array}$ & - & - \\
\hline Xing, 2013(59) & - & - & $\begin{array}{c}1.54^{\star} \\
(0.60-3.98)\end{array}$ & $\begin{array}{c}1.62^{\star} \\
(0.97-2.71)\end{array}$ & $\begin{array}{c}2.16^{\star} \\
(0.98-4.74)\end{array}$ & $\begin{array}{c}1.7^{\star} \\
(1.77-4.01)\end{array}$ & $\begin{array}{c}0.40 \\
(0.20-0.79)\end{array}$ & $\begin{array}{c}0.62 \\
(0.39-0.99)\end{array}$ \\
\hline $\mathrm{Xu}, 2013(60)$ & $\begin{array}{c}1.2 \\
(1.01-1.39)\end{array}$ & - & - & $\begin{array}{c}0.98^{*} \\
(0.80-1.16)\end{array}$ & $\begin{array}{c}1.67 \\
(1.13-2.22)\end{array}$ & $\begin{array}{c}0.98^{*} \\
(0.27-1.68)\end{array}$ & $\begin{array}{c}0.54 \\
(0.46-0.62)\end{array}$ & - \\
\hline $\begin{array}{l}\text { Majumder, } \\
2014(57)\end{array}$ & $\begin{array}{c}1.50 \\
(1.21-1.87)\end{array}$ & - & - & - & - & - & - & - \\
\hline Zhuang, 2014(61) & $\begin{array}{c}1.24 \\
(1.06-1.47)\end{array}$ & - & - & - & - & - & - & - \\
\hline
\end{tabular}

Data are expressed as odd ratio (95\% confidence intervals); *P values $\geq 0.05$, ns; $\mathrm{HBsAg}(+) / \mathrm{anti}-\mathrm{HBc}(+)$ : chronic carrier; $\mathrm{HBsAg}(-) / \mathrm{anti}-\mathrm{HBc}(+)$ : $\mathrm{past}$ exposure; anti-HBc(+)/anti-HBs(+): past exposure with natural immunity; $\mathrm{HBsAg}(+)$ : chronic or inactive carrier; anti-HBc(+)/anti-HBs(-): possibly chronically infected and have undetectable levels of $\mathrm{HBSAg}$ present in the serum $(\mathrm{OBI})$ 
and that some altered cellular signaling/ regulatory pathways are similar in PDAC and HCC (63).

Chronic pancreatitis and diabetes mellitus are well established conditions associated with high risk of developing PDAC $(39,43)$. Hence, HBV infection has been linked to these affections both by epidemiological and pathological analyses. HBV DNA and HBsAg were detected in pancreatic tissue or juice and were associated with development of chronic pancreatitis $(30,32-35,64)$. Chronic inflammation induced by $\mathrm{HBV}$ is known to participate eminently in liver tumorigenesis and might, therefore, contribute to development of PDAC as well (33). A significant synergistic effect between the presence of HBsAg and history of diabetes mellitus on PDAC risk was also highlighted in some studies $(33,40,45)$. Epidemiological connections between HBV infection and diabetes mellitus are supported at the histological level by the occasional strong expression of $\mathrm{HBsAg}$ and $\mathrm{HBcAg}$ in islet cells (33).

Other mechanisms suggested to induce carcinogenesis include HBV DNA integration in infected cells and subsequent protracted immune reaction of the host to clear the HBV-containing cells, a situation observed in HCC patients (45).

Besides, Chen and co-workers have shown that HBV X protein promotes PDAC trough modulation of the PI3K/ AKT signaling pathway (29).

Recently, Fiorino and co-workers have proposed a unified model that might explain the pancreatic carcinogenesis in patients with persistent HBV infection (65). This model hypothesizes that HBV-induced inflammation in the pancreas (and the liver as well) modifies the viscoelastic properties of the tissues. The increased stiffness generates a mechanical cellular stress that is translated by signaling pathways to produce an excess of radical oxygen species (ROS) leading on the long run to carcinogenesis.

\section{Is there any influence of $\mathrm{HBV}$ infection on clinico-pathological features and long-term outcomes in patients with PDAC?}

Previous studies have shown the impact of HBV in different malignancies $(27,28,37,66)$. In $\mathrm{HCC}$, our previous studies have shown significantly younger ages, male predominance and higher prevalence of liver cirrhosis, and less outside Milan criteria patients in the HBV-HCC group, compared with the non-viral HCC group of patients (27). However, no significant differences between groups were observed for postoperative mortality, diseasefree and overall survival rates (27). A recent study has shown that HBsAg(+) patients with any cancer types and positive have significantly younger ages at time of diagnosis, compared with the non-viral patients with corresponding cancers (37).

A role of $\mathrm{HBV}$ in PDAC might, thus, come together with changes in the presentation of the disease. One might say that assessing the impact of $\mathrm{HBV}$ infection in PDAC is challenging and its effects could be easily underestimated (29). Indeed, OBI and difficulties to detect $\mathrm{HBV}$ in pancreatic tissue remains major limitations $(29,33)$. Occult HBV infection is considered to play a role in promoting growth of tumors normally unrelated to the virus, and has been considered as a potential risk factor for development of several malignancies (67), including PDAC (58). Nevertheless, several studies have explored the potential impact of $\mathrm{HBV}$ in PDAC but have reached mixed conclusions.

Wang and co-workers have found that $\mathrm{HBsAg}(+)$ patients with PDAC are significantly younger and more predominantly males, compared with the PDAC patients never exposed to HBV infection (68). No differences were observed for tumor stage or grade of differentiation(68). The multivariate analysis did not find $\mathrm{HBsAg}$ positivity as risk factor modulating overall survival in PDAC patients (68).

Jin and co-workers observed that persistently HBV-infected patients with PDAC are significantly younger and increased rates of chronic 
pancreatitis, compared with patients without HBV infection (33). No differences were observed for gender, tumor size and stage or perineural invasion (33). Interestingly, patients with HBV infection displayed more frequently well-differentiated tumors albeit the statistical significance was not reached (33).

According to Wei and co-workers, patients with PDAC and chronic HBV infection are significantly younger and more predominantly males, compared with the non-viral PDAC patients (69). No differences were observed for tumor size and stage (69). The issue of sex is somewhat expected though, as males are known to be more susceptible than females to HBV chronic infection.

Chen and co-workers did not find any significant differences of $\mathrm{T}$ stage, vascular, perineural and lymph nodes invasion between patients with PDAC with or without HBsAg (29). However, shorter overall survival times were observed in the HBsAg positive group albeit statistical significance was not reached (29).

In a study conducted in China, chronic active infection with HBV was associated with statistically significant decreased rates of synchronous and metachronous metastases in patients with advanced PDAC and improved survivals for patients with stage IV PDAC, compared with patients with no HBV infection $(70,71)$. No differences were observed for inactive carriers (70). This observation is reminiscent of the fact that lower rates of liver metastases of colorectal cancer origin in patients with chronic liver diseases were previously highlighted in a meta-analysis (66). On the opposite, a previous study performed in China has shown significantly increased rates of synchronous liver metastases in patients with chronic HBV infection but no differences for general synchronous metastases, compared with the non-viral PDAC patients (69). In keeping with the work of Chen et al. significantly better overall survivals were observed for patients with chronic HBV infection (69).

Our previous studies have shown no significant differences between patients with pancreatectomies for PDAC, with or without positive $\mathrm{HBsAg}$, regarding age at diagnosis, gender, grade of differentiation, postoperative complications, completion of adjuvant therapy and overall survivals (72). However, tumor size and $\mathrm{T}$ stage tended to differ between the groups (72). Indeed, smaller tumors and earlier stages appear to be associated with HBV-PDAC patients albeit statistical significance was not reached (72). Nevertheless, this study had important limitations including overlooking of occult infection and past exposure to HBV infection and thus, its results should be regarded with caution (72).

Chemotherapy is frequently used for patients with PDAC in an adjuvant, neoadjuvant or palliative setting (1). It is known that reactivation of $\mathrm{HBV}$ is not uncommon in patients receiving chemotherapy (73) and the prognosis of these patients has been reported to be poor (74). Thus, HBV infection might have a detrimental effect on patients with PDAC receiving chemotherapy because reactivation of $\mathrm{HBV}$ may lead to severe hepatitis and death from fulminant liver failure or may contribute to delay or premature interruption of chemotherapy (73). Fortunately, not all chemotherapy regimens are associated with the risk of HBV reactivation; gemcitabine/ carboplatin, oxaliplatin and irinotecan-based chemotherapy which are the most frequent regimens used to treat PDAC appears to have low risk for HBV reactivation(75). As a consequence, the risk of HBV reactivation in patients with $\mathrm{PDAC}$ appears to be very low(73). Hence, the first case of reactivation of $\mathrm{HBV}$ infection following chemotherapy in a patient with PDAC was described only in 2002(76).

\section{Conclusions}

To date, and mostly based on epidemiological evidence, the available literature suggests the potential oncogenic role of HBV in PDAC even if the molecular evidence is scarce. Indeed, the putative instrumental role played by OBI in PDAC associated with difficulties inherent to HBV detection in pancreatic tissue remains major limitations to draw meaningful conclu- 
sions. In addition, HBV infection might influence some clinical and pathological features and it synergizes with selected $\mathrm{co}^{-}$ morbidities such as diabetes mellitus in patients with PDAC. Future researches to better define the role of $\mathrm{HBV}$ infection in developing PDAC are urgently needed.

\section{Funding and conflict of interests: none}

\section{References}

1. Goess R, Friess H. A look at the progress of treating pancreatic cancer over the past 20 years. Expert Rev Anticancer Ther 2018;18(3):295-304.

2. Wang Y, Schrag D, Brooks GA, Dominici F. National trends in pancreatic cancer outcomes and pattern of care among Medicare beneficiaries, 2000 through 2010. Cancer 2014;120(7):1050-8.

3. Weledji EP, Enoworock G, Mokake M, Sinju M. How Grim is Pancreatic Cancer? Oncol Rev 2016;10(1):294.

4. Siegel RL, Miller KD, Jemal A. Cancer statistics, 2018. CA Cancer J Clin 2018;68(1):7-30.

5. Brasoveanu V, Dumitrascu T, Bacalbasa N, Zamfir R. Splenic artery used for replaced common hepatic artery reconstruction during pancreatoduodenectomy-a case report. Chirurgia (Bucur) 2009;104(4):499-504.

6. Dumitrascu T, David L, Popescu I. Posterior versus standard approach in pancreatoduodenectomy: a case-match study. Langenbecks Arch Surg 2010;395(6):677-84.

7. Dumitrascu T, Dima S, Brasoveanu V, Stroescu C, Herlea V, Moldovan S, et al. Impact of a portal/superior mesenteric vein resection during pancreatico-duodenectomy for pancreatic head adenocarcinoma. Minerva Chir 2014;69(6):301-13.

8. Luberice K, Downs D, Sadowitz B, Ross S, Rosemurgy A. Has survival improved following resection for pancreatic adenocarcinoma? Am J Surg 2017;214(2):341-6.

9. Moldovan SC, Moldovan AM, Dumitraaecu T, Andrei S, Popescu I. The advantages of retropancreatic vascular dissection for pancreatic head cancer with portal/superior mesenteric vein invasion: posterior approach pancreatico-duodenectomy technique and the mesopancreas theory. Chirurgia (Bucur) 2012;107(5):571-8.

10. Popescu I, Dumitrascu T. Total meso-pancreas excision: key point of resection in pancreatic head adenocarcinoma. Hepatogastroenterology 2011;58(105):202-7.

11. Popescu I, Dumitrascu T. [Pancreatoduodenectomy-past, present and future]. Chirurgia (Bucur) 2011;106(3):287-96.

12. Zijlstra M, Bernards N, de Hingh IH, van de Wouw AJ, Goey SH, Jacobs EM, et al. Does long-term survival exist in pancreatic adenocarcinoma? Acta Oncol 2016;55(3):259-64.

13. Are C, Chowdhury S, Ahmad H, Ravipati A, Song T, Shrikandhe S, et al. Predictive global trends in the incidence and mortality of pancreatic cancer based on geographic location, socio-economic status, and demographic shift. J Surg Oncol 2016;114(6):736-42.

14. Malvezzi M, Carioli G, Bertuccio P, Boffetta P, Levi F, La Vecchia C, et al. European cancer mortality predictions for the year 2018 with focus on colorectal cancer. Ann Oncol 2018 Mar 19. doi: 10.1093/ annonc/mdy033. [Epub ahead of print]

15. Tiollais P, Chen Z. The hepatitis B. Pathol Biol (Paris) 2010; 58(4):243-4.

16. Global prevalence, treatment, and prevention of hepatitis B virus infection in 2016: a modelling study. Lancet Gastroenterol Hepatol 2018 Mar 26. pii: S2468-1253(18)30056-6. doi: 10.1016/S24681253(18)3005-6. [Epub ahead of print]
17. Pineau $P$, Tiollais $P$. [Hepatitis $B$ vaccination: a major player in the control of primary liver cancer]. Pathol Biol (Paris) 2010;58(6): 444-53.

18. Brechot C, Nalpas B, Courouce AM, Duhamel G, Callard P, Carnot F, et al. Evidence that hepatitis $B$ virus has a role in liver-cell carcinoma in alcoholic liver disease. N Engl J Med 1982;306(23):1384-7.

19. Tiollais $P$, Charnay $P$, Vyas GN. Biology of hepatitis $B$ virus. Science 1981;213(4506):406-11.

20. Tiollais P, Pourcel C, Dejean A. The hepatitis B virus. Nature 1985;317(6037):489-95.

21. Girard M. The Pasteur Institute's contributions to the field of virology. Annu Rev Microbiol 1988;42:745-63.

22. Brechot $C$, Kremsdorf $D$, Soussan $P$, Pineau P, Dejean A, PaterliniBrechot $P$, et al. Hepatitis B virus (HBV)-related hepatocellular carcinoma (HCC): molecular mechanisms and novel paradigms. Pathol Biol (Paris) 2010;58(4):278-87.

23. Tanase AM, Marchio A, Dumitrascu T, Dima S, Herlea V, Oprisan G, et al. Mutation spectrum of hepatocellular carcinoma from easternEuropean patients betrays the impact of a complex exposome. $J$ Expo Sci Environ Epidemiol 2015;25(3):256-63.

24. Andersen ES, Omland LH, Jepsen P, Krarup H, Christensen PB, Obel N, et al. Risk of all-type cancer, hepatocellular carcinoma, non-Hodgkin lymphoma and pancreatic cancer in patients infected with hepatitis B virus. J Viral Hepat 2015;22(10):828-34.

25. Kamiza AB, Su FH, Wang WC, Sung FC, Chang SN, Yeh CC. Chronic hepatitis infection is associated with extrahepatic cancer development: a nationwide population-based study in Taiwan. BMC Cancer 2016;16(1):861.

26. Sundquist K, Sundquist J, Ji J. Risk of hepatocellular carcinoma and cancers at other sites among patients diagnosed with chronic hepatitis B virus infection in Sweden. J Med Virol 2014;86(1):18-22.

27. Tanase AM, Dumitrascu T, Dima S, Grigorie R, Marchio A, Pineau P, et al. Influence of hepatitis viruses on clinicopathological profiles and long-term outcome in patients undergoing surgery for hepatocellular carcinoma. Hepatobiliary Pancreat Dis Int 2014;13(2):162-72.

28. Zhou Y, Si X, Wu L, Su X, Li B, Zhang Z. Influence of viral hepatitis status on prognosis in patients undergoing hepatic resection for hepatocellular carcinoma: a meta-analysis of observational studies. World J Surg Oncol 2011;9:108.

29. Chen $Y$, Bai X, Zhang Q, Wen L, Su W, Fu Q, et al. The hepatitis B virus $X$ protein promotes pancreatic cancer through modulation of the PI3K/AKT signaling pathway. Cancer Lett 2016;380(1):98-105.

30. Dejean A, Lugassy C, Zafrani S, Tiollais P, Brechot C. Detection of hepatitis $B$ virus DNA in pancreas, kidney and skin of two human carriers of the virus. J Gen Virol 1984:65 ( Pt 3):651-5.

31. Fiorino S, Visani M, Acquaviva G, Fornelli A, Masetti M, Cuppini A, et al. Search for HBV and HCV Genome in Cancer Cells of Pancreatic Tumors. Pancreas 2016;45(1):e12-e14.

32. Hohenberger $P$. [The pancreas as target organ for hepatitis $B$ virus-immunohistological detection of $\mathrm{HBsAg}$ in pancreatic carcinoma and chronic pancreatitis]. Leber Magen Darm 1985;15(2):58-63.

33. Jin $\mathrm{Y}, \mathrm{Gao} \mathrm{H}$, Chen H, Wang J, Chen M, Li G, et al. Identification and impact of hepatitis $B$ virus DNA and antigens in pancreatic cancer tissues and adjacent non-cancerous tissues. Cancer Lett 2013;335(2):447-54.

34. Shimoda T, Shikata T, Karasawa T, Tsukagoshi S, Yoshimura M, Sakurai I. Light microscopic localization of hepatitis B virus antigens in the human pancreas. Possibility of multiplication of hepatitis B virus in the human pancreas. Gastroenterology 1981; 81(6):998-1005.

35. Yoshimura M, Sakurai I, Shimoda T, Abe K, Okano T, Shikata T. Detection of HBsAg in the pancreas. Acta Pathol Jpn 1981;31(4):711-7.

36. Kwok RM, Tran TT. Hepatitis B and Risk of Non-Hepatocellular Carcinoma Malignancy. Clin Liver Dis 2016;20(4):693-702.

37. Wei XL, Luo HY, Li CF, Jin Y, Zeng ZL, Ju HQ, et al. Hepatitis B virus infection is associated with younger median age at diagnosis and death in cancers. Int J Cancer 2017;141(1):152-9. 
38. Fiorino S. HBV and HCV infection and pancreatic ductal adenocarcinoma. Hepatobiliary Pancreat Dis Int 2013;12(6):570-4.

39. Drouillard A, Manfredi S, Lepage C, Bouvier AM. [Epidemiology of pancreatic cancer]. Bull Cancer 2018;105(1):63-9.

40. Hassan MM, Li D, El-Deeb AS, Wolff RA, Bondy ML, Davila M, et al. Association between hepatitis B virus and pancreatic cancer. J Clin Oncol 2008;26(28):4557-62.

41. Hong SG, Kim JH, Lee YS, Yoon E, Lee HJ, Hwang JK, et al. [The relationship between hepatitis $B$ virus infection and the incidence of pancreatic cancer: a retrospective case-control study]. Korean J Hepatol 2010;16(1):49-56.

42. Liao KF, Lai SW, Li Cl, Chen WC. Diabetes mellitus correlates with increased risk of pancreatic cancer: a population-based cohort study in Taiwan. J Gastroenterol Hepatol 2012;27(4):709-13.

43. Pourhoseingholi MA, Ashtari S, Hajizadeh N, Fazeli Z, Zali MR Systematic review of pancreatic cancer epidemiology in AsiaPacific Region: major patterns in GLOBACON 2012. Gastroenterol Hepatol Bed Bench 2017;10(4):245-57.

44. Iloeje UH, Yang HI, Jen CL, Su J, Wang LY, You SL, et al. Risk of pancreatic cancer in chronic hepatitis $B$ virus infection: data from the REVEAL-HBV cohort study. Liver Int 2010;30(3):423-9.

45. Ben Q, Li Z, Liu C, Cai Q, Yuan Y, Wang K, et al. Hepatitis B virus status and risk of pancreatic ductal adenocarcinoma: a casecontrol study from China. Pancreas 2012;41(3):435-40.

46. Wang DS, Chen DL, Ren C, Wang ZQ, Qiu MZ, Luo HY, et al. ABO blood group, hepatitis $B$ viral infection and risk of pancreatic cancer. Int J Cancer 2012;131(2):461-8.

47. Zhu F, Li HR, Du GN, Chen JH, Cai SR. Chronic hepatitis B virus infection and pancreatic cancer: a case-control study in southern China. Asian Pac J Cancer Prev 2011;12(6):1405-8.

48. Chang MC, Chen CH, Liang JD, Tien YW, Hsu C, Wong JM, et al. Hepatitis B and C viruses are not risks for pancreatic adenocarcinoma. World J Gastroenterol 2014;20(17):5060-5.

49. Huang J, Magnusson M, Torner A, Ye W, Duberg AS. Risk of pancreatic cancer among individuals with hepatitis $C$ or hepatitis $B$ virus infection: a nationwide study in Sweden. Br J Cancer 2013; 109(11):2917-23

50. Abe SK, Inoue M, Sawada N, Iwasaki M, Shimazu T, Yamaji T, et al. Hepatitis $B$ and $C$ virus infection and risk of lymphoid malignancies: A population-based cohort study (JPHC Study). Cancer Epidemiol 2015;39(4):562-6

51. Tang J, Sharma R, Lamerato L, Sheehan M, Krajenta R, Gordon SC. Is previous exposure to hepatitis $B$ a risk factor for pancreatic cancer or hepatocellular carcinoma? J Clin Gastroenterol 2014; 48(8):729-33.

52. Berrington de Gonzales A, Yun JE, Lee SY, Klein AP, Jee SH. Pancreatic cancer and factors associated with the insulin resistance syndrome in the Korean cancer prevention study. Cancer Epidemiol Biomarkers Prev 2008;17(2):359-64.

53. Woo SM, Joo J, Lee WJ, Park SJ, Han SS, Kim TH, et al. Risk of pancreatic cancer in relation to $\mathrm{ABO}$ blood group and hepatitis $\mathrm{C}$ virus infection in Korea: a case-control study. J Korean Med Sci 2013;28(2):247-51.

54. Fiorino S, Chili E, Bacchi-Reggiani L, Masetti M, Deleonardi G, Grondona $A G$, et al. Association between hepatitis $B$ or hepatitis $C$ virus infection and risk of pancreatic adenocarcinoma development: a systematic review and meta-analysis. Pancreatology 2013;13(2):147-60.

55. Li L, Wu B, Yang LB, Yin GC, Liu JY. Chronic hepatitis B virus infection and risk of pancreatic cancer: a meta-analysis. Asian Pac J Cancer Prev 2013;14(1):275-9.

56. Luo G, Hao NB, Hu CJ, Yong X, Lu MH, Cheng BJ, et al. HBV infection increases the risk of pancreatic cancer: a meta-analysis. Cancer Causes Control 2013;24(3):529-37.

57. Majumder S, Bockorny B, Baker WL, Dasanu CA. Association
Between HBsAg Positivity and Pancreatic Cancer: a Meta-Analysis. J Gastrointest Cancer 2014;45(3):347-52.

58. Wang Y, Yang S, Song F, Cao S, Yin X, Xie J, et al. Hepatitis B virus status and the risk of pancreatic cancer: a meta-analysis. Eur $\mathrm{J}$ Cancer Prev 2013;22(4):328-34.

59. Xing S, Li ZW, Tian YF, Zhang LM, Li MQ, Zhou P. Chronic hepatitis virus infection increases the risk of pancreatic cancer: a meta-analysis. Hepatobiliary Pancreat Dis Int 2013:12(6):575-83.

60. Xu JH, Fu JJ, Wang XL, Zhu JY, Ye XH, Chen SD. Hepatitis B or C viral infection and risk of pancreatic cancer: a meta-analysis of observational studies. World J Gastroenterol 2013;19(26):4234-41.

61. Zhuang H, Shi Z, Hu P, Ren H, Zhang D. [Association between hepatitis $B$ virus infection and risk of pancreatic cancer: a metaanalysis]. Zhonghua Gan Zang Bing Za Zhi 2014;22(6):416-9.

62. Hohenberger P. Detection of $\mathrm{HBs}-\mathrm{Ag}$ in the pancreas in cases of pancreatic carcinoma. Hepatogastroenterology 1984;31(5): 239-41.

63. Fiorino S, Lorenzini S, Masetti M, Deleonardi G, Grondona AG, Silvestri $T$, et al. Hepatitis $B$ and $C$ virus infections as possible risk factor for pancreatic adenocarcinoma. Med Hypotheses 2012; 79(5):678-97.

64. Hoefs JC, Renner IG, Askhcavai M, Redeker AG. Hepatitis B surface antigen in pancreatic and biliary secretions. Gastroenterology 1980;79(2):191-4.

65. Fiorino S, Bacchi-Reggiani L, Pontoriero L, Gallo C, Chili E, Masetti $M$, et al. Tensegrity model hypothesis: may this paradigm be useful to explain hepatic and pancreatic carcinogenesis in patients with persistent hepatitis B or hepatitis C virus infection? JOP 2014; 15(2):151-64.

66. Cai B, Liao K, Song XQ, Wei WY, Zhuang Y, Zhang S. Patients with chronically diseased livers have lower incidence of colorectal liver metastases: a meta-analysis. PLoS One 2014;9(9):e108618.

67. Nishikawa $H$, Osaki Y. Clinical significance of occult hepatitis $B$ infection in progression of liver disease and carcinogenesis. J Cancer 2013;4(6):473-80.

68. Wang DS, Wang ZQ, Zhang L, Qiu MZ, Luo HY, Ren C, et al. Are risk factors associated with outcomes in pancreatic cancer? PLoS One 2012;7(7):e41984.

69. Wei XL, Qiu MZ, Chen WW, Jin Y, Ren C, Wang F, et al. The status of HBV infection influences metastatic pattern and survival in Chinese patients with pancreatic cancer. J Transl Med 2013;11:249.

70. Chen $Q$, Ning Z, Wang L, Ying H, Dong S, Zhang C, et al. Is chronic hepatitis $B$ infection a protective factor for the progression of advanced pancreatic ductal adenocarcinoma? An analysis from a large multicenter cohort study. Oncotarget 2016;7(51):85603-12.

71. Deng QL, Dong S, Wang L, Zhang CY, Ying HF, Li ZS, et al. Development and Validation of a Nomogram for Predicting Survival in Patients with Advanced Pancreatic Ductal Adenocarcinoma. Sci Rep 2017;7(1):11524.

72. Dumitrascu T, Pineau P, Dima S, Stroescu C, Brasoveanu V, Herlea V, et al. Impact of Hepatitis B Virus on Clinicopathological Features and Outcomes After Resection for Pancreatic Adenocarcinoma. Anticancer Res 2015;35(9):5123-8.

73. Lubel JS, Angus PW. Hepatitis B reactivation in patients receiving cytotoxic chemotherapy: diagnosis and management. $J$ Gastroenterol Hepatol 2010;25(5):864-71.

74. Ikeda M. Reactivation of hepatitis $B$ virus in patients receiving chemotherapy. Jpn J Clin Oncol 2013;43(1):8-16.

75. Ling WH, Soe PP, Pang AS, Lee SC. Hepatitis B virus reactivation risk varies with different chemotherapy regimens commonly used in solid tumours. Br J Cancer 2013;108(10):1931-5.

76. Oksuzoglu B, Kilickap S, Yalcin S. Reactivation of hepatitis B virus infection in pancreatic cancer: a case report. Jpn J Clin Oncol 2002;32(12):543-5. 